Przegląd Prawa Konstytucyjnego

-ISSN 2082-1212--------

DOI 10.15804/ppk.2017.01.12

$-\mathrm{Nr} 1(35) / 2017$

\title{
Recenzja
}

\section{Wojciech Mojski, Konstytucyjna ochrona wolności wypowiedzi $w$ Polsce, ISBN 978-83-63761-49-3, Towarzystwo Wydawnictw Naukowych „Libropolis”, Lublin 2016, ss. 189}

W recenzowanej monografii Wojciech Mojski zajął się problematyką konstytucyjnej ochrony wolności wypowiedzi w Polsce. Autor wybierając ten temat nie podjął się, co prawda, analizy zagadnienia nowego dla literatury z zakresu polskiego prawa konstytucyjnego. Literatura ta jest obszerna i umożliwia wszechstronne zapoznanie się z tą problematyką. W żadnym jednak stopniu nie umniejsza to wartości naukowej recenzowanej monografii. Poszczególne opracowania dotyczą bowiem szczegółowych aspektów konstytucyjnej ochrony wskazanej wolności w Polsce, a nie kompleksowej analizy tego zagadnienia, a Autor podjął się próby całościowej analizy ochrony wolności wypowiedzi w ramach polskiego systemu konstytucyjnego i już w tym miejscu można zauważyć, że uczynił to w sposób rzetelny, nowatorski i przekonujący.

Książka składa się ze wstępu, trzech rozdziałów i zakończenia. Poszczególne jej części tworzą przemyślaną i spójną całość, w której można odczytać zamysł Autora, aby podjęty temat zrealizować poprzez wyróżnienie części wprowadzającej (Wstęp), teoretycznej (Rozdział I), normatywnej (Rozdział II), praktycznej (Rozdział III), a także zawierającej wnioski (Zakończenie). Na szczególne podkreślenie zasługuje przy tym wyróżnienie w monografii części teoretycznej, w której analizie poddane zostały uwarunkowania ochrony wolności wypowiedzi w każdym demokratycznym państwie praw- 
nym. W kolejnych dwóch częściach odnosi je bowiem Autor do norm polskiego porządku konstytucyjnego i praktyki ich stosowania w Polsce, a w Zakończeniu formułuje ważne i odnoszące się nie tylko do Polski wnioski.

Przechodząc do szczegółowej analizy struktury książki, warto zauważyć, że we Wstępie (str. 9-12), poza ogólnym tłem podjętych w niej rozważań, W. Mojski wskazał również na jej podstawowy cel. Celem tym była w założeniu Autora próba ustalenia czynników, które mają wpływ na to, że po „kilkunastu latach obowiązywania w Polsce nowej demokratycznej konstytucji i szerokim związaniu się przez państwo polskie prawem międzynarodowym i ponadpaństwowym w kontekście ochrony wolności wypowiedzi, nadal pojawiają się istotne problemy prawne związane z tą wolnością" (str. 10). Lektura książki pozwala stwierdzić, że konsekwentnie zmierza on do osiągnięcia założonego celu w kolejnych częściach monografii i czyni to w sposób interesujący i pogłębiony.

Rozdział pierwszy monografii Wojciecha Mojskiego pt.: „Uwarunkowania ochrony wolności wypowiedzi w demokratycznym państwie prawnym” (str. 13-42) poświęcony jest jego rozważaniom odnoszącym się do komunikacji interpersonalnej jako faktycznego korelatu wolności wypowiedzi, założeniom normatywnej teorii jej ochrony oraz aksjologicznym czynnikom dotyczącym gwarancji tej wolności w demokratycznym państwie prawnym. $\mathrm{W}$ rozdziale tym przeanalizowane zostały również kwestie odnoszące się do podstawowych problemów praktyki ustrojowej ochrony wolności wypowiedzi w takim państwie.

W rozdziale drugim „Konstytucyjny model ochrony wolności wypowiedzi w Polsce" Autor przedstawia polski model konstytucyjny ochrony wolności wypowiedzi, zrekonstruowany na podstawie przepisów Konstytucji oraz przepisów Europejskiej Konwencji Praw Człowieka, Karty Praw Podstawowych Unii Europejskiej i Międzynarodowego Paktu Praw Obywatelskich i Politycznych ONZ.W. Mojski analizuje w tym rozdziale wskazane akty pod kątem zawartych w nich gwarancji wolnej wypowiedzi, wzbogacając swoje wnioski o ich interpretację dokonywaną w opracowaniach doktrynalnych oraz w orzeczeniach Trybunału Konstytucyjnego, Europejskiego Trybunału Praw Człowieka, a także Komitetu Praw Człowieka ONZ.

W kończącym monografię rozdziale trzecim „Konstytucyjne problemy ochrony wolności wypowiedzi w Polsce" (str. 119-156) Autor przeanalizował 
główne problemy konstytucyjne związane z praktyką ochrony wolności wypowiedzi w Polsce. W ramach podziału przyjętego $\mathrm{w}$ tym rozdziale analizie poddane zostały na wstępie uwarunkowania konstytucyjnej praktyki ochrony wolności wypowiedzi w Polsce, a następnie w kontekście tych uwarunkowań, generalne i szczegółowe problemy związane z regulacjami normatywnymi polskiego porządku prawnego dotyczącymi wypowiedzi zniesławiających, znieważających, „antydemokratycznych” i nienawistnych, a także tych, które dotyczą wolności wypowiedzi prasy i innych środków społecznego przekazu.

Na bardzo pozytywną ocenę zasługuje wykorzystana w pracy baza źródłowa. Co prawda nie wykorzystano w książce wszystkich dostępnych źródeł bibliograficznych dotyczących analizowanej tematyki, tak w języku polskim, jak i tym bardziej w literaturze obcojęzycznej, jednakże nie można uczynić z tego zarzutu. Autor w sposób dojrzały i wskazujący na pogłębioną analizę poruszanej tematyki, dobrał do poruszanych przez siebie kwestii właściwe opracowania doktrynalne, jak też egzemplifikujące analizowane problemy orzeczenia TK, ETPCz i uwagi KPCz ONZ.

W Zakończeniu monografii (str. 157-168) Wojciech Mojski zawarł ciekawe wnioski z przeprowadzonych badań, których najlepszym podsumowaniem jest następujący fragment, dotyczący ochrony wolności wypowiedzi w każdym współczesnym demokratycznym państwie prawnym, w tym także w Polsce: „Duży stopień uwikłania aksjologicznego ochrony wolności wypowiedzi przesądza zarazem jednak o niemożliwości ferowania w pełni obiektywnych i powszechnie akceptowalnych rozstrzygnięć w kwestiach szczegółowych. Odnosi się to zarówno do opinii społecznej, poglądów doktrynalnych, rozstrzygnięć prawodawczych, jak i rozstrzygnięć orzeczniczych. W istotnym zakresie konkretne rozstrzygnięcia mają bowiem charakter subiektywnych ocen odnoszących się do danego kontekstu ochrony wolnej wypowiedzi. Subiektywizacja tych ocen jest jednak czymś nieuniknionym w demokratycznym państwie prawnym". Pogląd ten nie rozstrzyga wszelkich wątpliwości dotyczących ochrony wolności wypowiedzi w Polsce. Nie sposób jednak nie podzielić tego poglądu, gdyż przeprowadzona w monografii analiza w istocie przekonuje o zasadności wniosku, że dyskusja o istocie i granicach wolności słowa w Polsce zawsze będzie budziła wiele sporów i emocji, które jak wykazał Autor są wynikiem przyjętej koncepcji ustrojowej państwa demokratycznego. 
Zaprezentowane powyżej zalety monografii Wojciecha Mojskiego, wpływają nie tylko na to, że zasługuje ona na rekomendację jako wartościowa pozycja naukowa, skierowana przede wszystkim do teoretyków i praktyków nauk prawnych. Dodatkowo można wskazać, że recenzowana monografia może stanowić ciekawe źródło wiedzy i refleksji dla szerszego kręgu czytelników. Można ją polecić zarówno studentom kierunków prawniczych, politologicznych i dziennikarskich, ale także czytelnikom, którzy zainteresowani są po prostu ochroną w Polsce jednej z najistotniejszych wolności człowieka.

Sabina Grabowska Uniwersytet Rzeszowski 